\title{
The effect of smart school programs on EFL reading comprehension in an academic context
}

\author{
Rostami, Soroor \\ English Department, Imam Reza International University, Mashhad, Iran (rostami.soroor@yahoo.com) \\ Akbari, Omid \\ English Department, Imam Reza International University, Mashhad, Iran (omidakbari777@yahoo.com) \\ Ghanizadeh, Afsaneh $\bowtie$ \\ English Department, Imam Reza International University, Mashhad, Iran (ghanizadeafsane@yahoo.com; \\ afsanehghanizadeh@gmail.com)
}

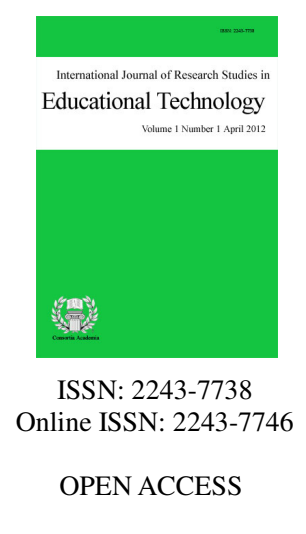

Received: 13 October 2014

\section{Abstract}

The present study investigated the impact of Smart Schools Programs on the learners' reading comprehension ability in an EFL (English as a Foreign Language) context. In so doing, the study utilized an experimental design with 64 participants in the control group and 60 participants in the experimental group who were students of junior high school grade one in Mashhad. The results of a pretest indicated that the participants of the two groups were homogenous with regard to their proficiency level. In addition to the main course book, the experimental group was exposed to Smart School software program, smart board, Power Point Presentation (P.P.P.), and World Wide Web (Internet) but in control group the main course book was just taught through traditional chalk and board instruction. Moreover, after the interval of three weeks a delayed post-test was administered to check the participants' recall rate of reading knowledge by the two groups. The results of the post-test indicated that Smart Schools Programs have a positive and significant influence on learners' reading comprehension ability. Moreover, in the delayed post-test, experimental group showed significantly higher scores than the traditional group.

Keywords: smart schools programs; reading comprehension; EFL; smart school software 


\section{The effect of smart school programs on EFL reading comprehension in an academic context}

\section{Introduction}

One of the achievements of information technology and communication is Smart Schools Creation. Smart School is a physical school which is controlled and managed by computer and network technology; the content of its courses is electronic and its evaluation and monitoring system is intelligent. Also the visual - auditory contents are developed in an attractive environment and increase operational capabilities. And this point is to allow school officials to replace blackboard and traditional homework with computer and CD in smart schools. Students are provided with internet access and get information easily about any topic they want (Soltani, 2012). Majidi (2010) mentioned "In this system, key elements for any change, is a change in thinking and tools and facilities are only a means to cover the thoughts". In Smart schools, teachers can work in schools rather than try to find own answers for students questions, they want them to find answer of questions on the computer and tell them to others. Smart School is a school of education systems with modern technologies and smart-looking digital part to speed the process of teaching and learning (Majidi, 2010).

In Iran, the smart school project has been affected by a similar project undertaken by the Malaysian Ministry of Education (Attaran \& Siraj, 2010). In Malaysia, the idea of smart schools was proposed in 1997 and became operational in 1999. Seventy-eight million dollars were allocated to the project, providing educational material (Puteh \& Vicziany, 2004). Patterned on the Malaysian model, the smart school project in Iran was launched in 2004. By publishing "The Road Map of Iranian Smart Schools" in 2011 at the pilot stage, the project was extended to other educational districts. The main focus at this stage was equipping the smart schools with computers, smart boards, network facilities and so forth. Like many other countries, an implicit assumption seems to be dominant in the project: that by equipping schools with computer hardware, ICT integration will turn into a mainstream trend (Thang, Hall, Azman, \& Joyes, 2010).

The common educational system in Iranian schools relies on a traditional teaching or in other words mainly on hearing. The visual education is usually limited to placing colorful posters on the blackboard. In visual-hearing education it is tried to educate using animation films, music etc. In this method the material is nearly retained for twenty years and at the same time permanency of the material in the hearing method is nearly six months. In addition in the hearing-visual method the scientific materials are conveyed in a more interesting and less time-consuming environment. In ordinary schools the teachers' lesson plan is comprised of some of the instructions, lesson plans, additional tests and classroom quizzes, etc. but in multimedia classes in addition to these materials multimedia education supplies including film, picture, voice and slides are used to increase the quality and permanence of the learning materials. This is the first step towards smart schools (Parsa, 1995).

One area of language learning for which rich resources can be found on the Internet, is reading comprehension. Reading is a source of learning and a source of enjoyment. It provides important opportunities for second language (L2) development (Day \& Bamford, 1998). However, sources of L2 input are often limited for learners in EFL setting especially in Iranian language learning system. Other factors influencing the reading comprehension achievement might be due to environmental constraints such as students' diversity in reading abilities, the socio-economic gap between urban and rural students, class size, time constraints, and available resources such as audio-visual materials and more recently Internet resources usage in classroom which are highly important in student motivation and achievement (Abdi, 2013).

According to Godwin-Jones (1998), the Internet resources can solve these problems by using as a supplement to, and improvement of, traditional EFL teaching. He also mentioned that it provides native speakers' voice and motion pictures which are interesting and learners work with them enthusiastically. 


\subsection{Research questions}

Inasmuch as the purposes of the study are to investigate the effect of smart school programs on EFL learners' reading comprehension ability and the recall rate of the acquired knowledge, this study addresses the following questions:

$\mathbf{Q}_{1}$. Do Smart Schools Programs have any impact on the learners' reading comprehension ability?

$\mathbf{Q}_{2}$. Is there any relationship between the application of smart schools programs to learn reading comprehension and the EFL learners' longer retention of the acquired knowledge?

\subsection{Research hypotheses}

The following null hypothesis is proposed:

H1: there is no significant difference between the means scores of the group instructed in the smart school (experimental group) and the group instructed with traditional system (control group).

H2: there is no relationship between the application of smart schools programs to learn reading comprehension and the EFL learners' longer retention of the acquired knowledge.

\section{Review of Literature}

Abdi (2013) studied the effectiveness of using hypertext materials on reading comprehension ability of learners as compared to the normally written materials. He indicated that hypertext materials have positive effect on reading comprehension ability of Iranian EFL learners. Also, Bahmani, Keshavarz, and Ghajari (2013) in the same year studied the effect of smart schools on the social skills of students. The result of the study indicated that smart schools are effective in improving the general dimensions of social skills. Esmaeili Fard and Nabifar (2011) examined the effect of Computer Assisted Language Learning on reading comprehension in an EFL context. Result of this study revealed that the students who were taught by CALL instructional significantly outperformed than students who were taught by the traditional printed text. So, they substantiated Preston and Mowbray's contention (2008) that teachers improve their instruction by using a variety of technology resources such as the Internet, multimedia CD-ROMs, audio and graphics.

Also computer technology provides teachers and students with a whole new interactive learning environment to share ideas, information, images, animations, audio or video. It has been more than 50 years researchers in education noticed that if students and teachers are really involved in learning procedures, learning process would be better and quicker, and if full potentiality of learners' intelligence in acquiring information is salvaged, the level of learning would be facilitated to a higher level. Therefore, if multimedia technologies make direct relationship between learners and teachers -making a multi-dimensional cooperation possible- they would eventually assist teachers in facilitating learning procedures by making them interesting and fun (Zufen, 2006). Data gathered from the research by Uneeco (2003) and Zain and Murugaiah (2004) have indicated that in smart schools teachers can ask students to find the answers to their questions through web or computer resources instead of answering their questions themselves and negotiate their answers with their classmates. Smart schools even have the utility of showing their students that some web resources are trustworthy and some others are not. Moreover, Kulik and Kulik (1991) surveyed more than 500 studies which compared learners who received computer-assisted instruction with the learners who received traditional instruction. They found that learners tend to learn more and in less time with computer-assisted learning.

Although extensively welcomed by teachers and institutions and despite all constructive and distinctive characteristics of the Internet, some disadvantages of using the Internet in the field of education should also be taken into consideration. As Attaran, Alias, and Siraj (2012) mentioned that although using smart schools has positive points, they have negative points as well; so by conducting precise experiments and making sound 
Rostami, S., Akbari, O., \& Ghanizadeh, A.

decisions the threats can be identified and be changed to opportunities. Moreover, research findings of Wan Ali, Mohd Nor, Hamzah, and Alwi (2009) show that time, course content and technical malfunction were the main problems teachers faced during the process of ICT integration in Malaysian smart schools.

Also, Mahmoudi, Nalchigar, and Ebrahimi (2008) in their research, found that the basic challenges of Iranian smart schools were the lack of necessary rules and regulations in the Ministry of Education and the traditional structure of Iranian schools. In addition, Wood (2004) declared that the enormous quantity of information found on the Internet makes learners confused when they try to find specific information, it may not be easy to obtain the explicit information while searching for the required topic. When the information has been obtained, learners may not be able to analyses it critically or make assumption whether the information is suitable, reliable, or valuable for them to use. Soltani (2012) mentioned some of Smart School Goals such as: All- round development of students (physical, mental, emotional and psychological), improving individual's promotion and abilities, training thinker and user of technology human resources, and increasing public participation. He also declared seven principles keys of smart schools are: A creative knowledge, talent to learn, according to the understanding, learning with control and transfer goals, overcome difficulties, evaluation learned, and schools as an educational organization.

\section{Methodology}

\subsection{Participants}

The population in this study consists of 124 female students studying in the first grade of high school at two different high schools (Farhang and Tolue Fajr) in Mashhad, Khorasan Razavi, Iran. They were divided into control and experimental groups. There were 60 learners in the experimental and 64 learners in the control group. The pretest $\left(T_{1}\right)$ indicated that two groups were homogenous in terms of English language proficiency. The female teacher of both groups was the same to remove all of the possible effect of teacher's personality.

\subsection{Instruments}

The instruments which were used in the study are as follows:

Instruments used for the treatments - The course materials used in this research for the treatments included Smart School software program, smart board, Power Point Presentation (P.P.P), and World Wide Web (Internet). Moreover, the participants in the experimental group were using these instruments while in the classes where the control group used to attend; there was no trace of new technology of any sort at all.

The materials used for data collection - The materials used for data collection included tests and the direct observations. KET which is a standardized test conducted as pre-tests, post-tests, and delayed post-tests. Key English Test (KET), a standardized test published by Express Publishing in 2000 contains 4 parts, drawn from authentic sources (Part1-Signs, Part2- Definitions, Part3- Verbal Exchange Patterns and Part4- Factual Text).

\subsection{Design}

In the real world in which school and classes exist, serious limitations are placed on the freedom of researchers to manipulate and control the conditions under which they conduct research. Moreover, language program administrators are generally unwilling to disturb their ongoing programs and allow reorganization of classes in order to randomize the subjects to different experimental group. In the present study one group was taught by using smart school program while the other group was taught using a traditional method of instruction in a traditional classroom setting. The experimental group is called group 1 and the control group is called group 2. The subjects weren't randomized. So, Quasi Experimental design was chosen in this study. 


\subsection{Data collection procedure}

The study was carried out in winter and spring 2014 for 8 sessions. To make sure that students of both groups were homogenized on the part of language proficiency, two groups were examined by KET test $\left(\mathrm{T}_{1}\right)$ as pre-test on the first session. Each student had 60 minutes to answer all of the items. If they needed any explanation due to any problems in understanding the items, the teacher provided required explanation. From the second session on, experimental group was taught through the smart school program. The learners practiced reading comprehension by the smart software and students-made Power Point Presentations. They also searched through the web sites for the unknown vocabularies. For abstract vocabularies, the teacher found the images through web sites. So, the teacher took the advantage of using technology in the experimental group. However, the same teacher taught the control group through traditional chalk and board instruction. They learned the same reading text without the presence of computers and were encouraged to read the reading texts aloud, guess the meaning of unknown vocabularies and look up them in their dictionaries with the help of the teacher. Both groups were obliged to take part in each session. They had to review at home whatever had been covered in each session. Then in the next step of the study, in order to examine the possible impact of treatment on students, KET test $\left(\mathrm{T}_{2}\right)$ were given to students on the seventh session. After the interval of 3 weeks, students were given the parallel form of immediate post-tests as the delayed post-tests $\left(\mathrm{T}_{3}\right)$ on the last session to examine the recall rate of reading knowledge by the two groups.

\section{Results}

Table 1 and 2 are displaying all the data related to groups 1 and 2 in all the measurements, including the mean, standard deviation, maximum and minimum scores, and standard error of the mean in each test individually. The comparison of these scores appears in the following pages. These abbreviations are used in the tables of results standing for the meanings in the parentheses: Group 1: (Experimental group), Group 2: (Control Group), $\mathrm{T}_{1}$ : (pre-test), $\mathrm{T}_{2}$ : (post-test), $\mathrm{T}_{3}$ : (Delayed post-test) and $\mathrm{N}$ : (Number of participants).

\section{Table1}

Representative Data of the Performance of Group 1 in All Tests

\begin{tabular}{lccc}
\hline Time & pre-test & post-test & Delayed post-test \\
\hline Test & $\mathrm{T}_{1}$ & $\mathrm{~T}_{2}$ & $\mathrm{~T}_{3}$ \\
Mean & 15.000 & 16.4500 & 15.0167 \\
Std. Deviation & 3.81345 & 3.49054 & 3.78441 \\
Maximum & 20 & 20 & 20 \\
Minimum & 7.00 & 8.00 & 5.00 \\
Std. Error & .49231 & .45063 & .48857 \\
\hline
\end{tabular}

Table 2

Representative Data of the Performance of Group 2 in All Tests

\begin{tabular}{lccc}
\hline Time & pre-test & post-test & Delayed post-test \\
\hline Test & $\mathrm{T}_{1}$ & $\mathrm{~T}_{2}$ & $\mathrm{~T}_{3}$ \\
Mean & 14.500 & 14.7656 & 12.4375 \\
Std. Deviation & 4.14039 & 3.93092 & 3.91122 \\
Maximum & 20 & 20 & 19.00 \\
Minimum & 7.00 & 7.00 & 4.00 \\
Std. Error & .51755 & .49137 & .48890 \\
\hline
\end{tabular}

To examine the pre-existing differences between the students' proficiency level in the two groups, an 
Rostami, S., Akbari, O., \& Ghanizadeh, A.

independent sample $t$-test was performed between the mean scores of control and experimental groups. Simply put, the t-test aimed at looking for any significant difference between the two groups in relation to their level of language proficiency. When the variances of these scores in both groups, were equal, the amount of $p$-value was higher than 0.05. It means: For T1 $\Rightarrow p$-value $=0.486 \geqslant \alpha=0.05$

It shows that with confidence interval of difference of $95 \%$, there is no significant difference between the mean scores of the control and experimental groups. It means that students of control and experimental groups are homogenous on the part of their English language proficiency in T1 (table 3).

Table 3

Independent Samples t-test for pre-tests

\begin{tabular}{lccccc}
\hline & Sig. & $t$ & $d f$ & Mean Difference & Std. Error Difference \\
\hline Score & .486 & .698 & 122 & .5 & .71621 \\
\hline
\end{tabular}

To answer the first research question, after the treatment and at the end of the term, an independent samples $t$-test was performed between the mean scores of the post-tests of the two groups. Table 4 shows the details. The results of the $t$-test indicated that there was a significant difference between the mean scores of the control and experimental groups at the end of the term in post-test because: $p$-value $=0.013<\alpha=0.05$

\section{Table 4}

Independent Samples t-test for post-tests

\begin{tabular}{cccccc}
\hline & Sig. & $t$ & $d f$ & Mean Difference & Std. Error Difference \\
\hline Score & .013 & 2.517 & 122 & 1.68437 & .66928 \\
\hline
\end{tabular}

The mean score of control group in post-test was 14.7656 and the mean score of experimental group in post-test was 16.450 , while the mean score of control group was 14.450 in pre-test and this score was 15.000 for experimental group. It showed that the mean score of experimental group has increased in post-test, but this score has a little increased in post-test of control group which didn't receive the treatment.

\section{Table 5}

Independent Samples t-test for post-tests

\begin{tabular}{cccccc}
\hline & Sig. & $t$ & $d f$ & Mean Difference & Std. Error Difference \\
\hline Score & .000 & 3.728 & 122 & 2.57917 & .69191 \\
\hline
\end{tabular}

The main issue which is followed by doing $T_{3}$, is to test if applying smart school programs influences the learner's recall rate or not. To answer the second research question, an independent samples $t$-test was performed between the mean scores of the delayed post-tests of the two groups. Table 5 shows the details. The mean score of control group in delayed post-test was 12.43 and the mean score of experimental group in delayed post-test was 15.0167 . The results showed that in the delayed post-test, experimental group showed significantly higher scores than the traditional group. As Table 5 indicates, $p$-value $=0.00<\alpha=0.05$. So, it can be concluded that the application of smart school programs to reading comprehension positively and significantly influences the EFL learners' longer retention of the acquired knowledge.

\section{Discussion and Conclusion}

As the results of this study indicate, the students who were taught by Smart School Program significantly outperformed the students who were taught by the traditional teacher-centred methods of teaching reading comprehension which invest the total time of the class on the grammatical structures of the passages, rigid vocabulary memorization, and translational exercises with no sign of technology which are congruent with 
viewing reading as a passive skill. However, we are not able to find any previous studies with which these findings could be directly compared. This explains the novelty and distinctiveness of this study, and reflects the infancy of the Smart Schools Initiative. Nevertheless, comparison could still be made based on the logic of parallel impact of other technology-based curricular innovations so long as their distinctive features are clearly identified. When comparing the results of this study with the results of the previous related literature, we found that this study is consistent with many practical studies this study is consistent with many practical studies which were conducted before (e.g., Marzban, 2011; Huang \& Pan, 2009; Lan, Sung, \& Chung, 2006; Simsek, 2008). It is consistent with the research findings of Marzban (2011) which showed that using computer assisted educational techniques can improve students' reading comprehension ability.

Simsek (2008) investigated the students' attitudes toward integrating of ICTs in a reading course and found that the students were satisfied overall with the application of ICTs in their reading course and developed positive attitudes toward online course. Findings of the present study are also in line with those of Lan et al., (2006) who claimed that Internet-based EFL reading may emerge as a flexible and portable solution to the pedagogical challenges that exist in conventional EFL reading and teaching environment. By analyzing qualitative and quantitative data of their research, they concluded that with the support of wireless peer assisted learning system, students made greater progress in learning to read compared with who did not use the system. Huang and Pan (2009), also, indicated how Internet-based learning system had positive impact on students reading comprehension and motivation.

On the other hand, the results of the current study are different from those of some other which reported that online EFL learning systems did not benefit students' English reading comprehension (Liu, 2007; Yang Wong, \& Yuh, 2008). Moreover, a study conducted by Ong and Kenneth Ruthven (2010) show that even though Smart School projects intended to prepare the younger generation for scientific and technological careers, they have failed to accord with expectations. Thang et al. (2010) attributed this fail to inadequate teacher training. They claimed that teachers in smart schools have not been fully instructed to manage the process of ICT integration into education. Also, Attaran and Siraj (2010) showed that teachers and students do not hold a positive attitude towards teaching and studying in Iranian smart schools. Furthermore, the results of their study revealed that in order to increase the efficiency of smart schools, educational institutions should be provided with further equipment, and teachers should attend ICT training courses, undergo extra training and receive benefits for their participation in such courses. Moreover, educational courses for the students should be presented through diverse models that correspond to their talents. Traditional routines in class should be abandoned and each class should be equipped with computers and peripheral devices.

In the last decades, foreign language teaching and learning have been dominated by communicative language teaching methods and interactionist theories. Since the adoption of these approaches, interaction has become paramount in teaching programs and courseware products both as the learning aim and as the best tool to develop the learner's second language communicative skills. Although it seems obvious that reading should play an important role within such a language curriculum, the training of this skill is still often neglected within second language classroom instruction. Most of the time in ordinary classes reading is at the end of the class and students are often feeling bored after an hour practicing on the other sections. Studies in Iran show that both teachers and students like to skip reading and they think it is not an important skill among the other skills (Marzban, 2011).

\subsection{Implication}

The results of the present study lead to the conclusion that the students who were taught by Smart School Program significantly outperformed the students who were taught by the traditional teacher-centred methods of teaching reading comprehension. Smart School Program by having an account of the significances of the communicative approach and its role in the establishment of an atmosphere in which learners learn the language through meaningful interaction and exchanging of genuine information, learners can take a more active role. One 
of the most important aspects of using technology in the classroom is that students are free from anxiety and there is no peer pressure which inhibits them from language learning easily. Hence, it seems in this fast-paced and ever-changing world we live in, network technology is not a mere luxury; it should be viewed as a basic survival skill. Furthermore, to survive in the global borderless world, each country, each organization, and individual needs to grasp the essence of globalization which is highly dependent on new technologies and equipment. This rapid global technological development has dramatically influenced educational systems. One of the most critical objectives of education in this era is to equip learners with life-long learning, thinking skills, creativity, social skills, and self-regulation. Lack of these skills and abilities not only threatens students' survival in this data-driven and technology-based world, but also makes problems for the whole educational system and whole society.

Eliminating these potential problems and attaining these life-long skills entail a redefinition of roles and effectiveness of schools as a main educational party in the society. A shift in roles through which students feel responsible for their learning and the kind of schooling in which new technologies are integrated with every teaching and learning endeavor. Educational systems all over the world have responded to these challenges in different forms to enable their students to adapt and absorb these changes into education. A very common solution has been the integration of technology-based curriculum and computer assisted learning into mainstream education. According to the findings of the present study, schools equipped by these technologies facilitate language learning and teaching. Thus, teachers are advised to vary their methods, techniques and ways of teaching, according to their students' needs and interests. They are also advised to use the computerized method more intensively and more frequently. The fulfillment of Smart School's mission requires time, money, and dedication, but there is pay-off eventually. This, in turn, necessitates exploiting and developing courses and preparation programs for EFL teachers focusing on skills associated with ICT to help them for their participation in such courses. These programs should be specifically targeted at less experienced and elder teachers who themselves have not experienced such things before. Furthermore, educational institutions should be provided with further equipment to let all the learners use them freely.

\subsection{Suggestions for further research}

To the researchers' best knowledge, this is the first attempt to explore the relationship between smart schools programs and learners' reading comprehension ability. Thus, this study should be replicated. Since this study was conducted only in first high school level, further research is needed in other levels in order to compare the results. Moreover, in the current study, students' gender was not considered. The relationship between smart schools programs and learners' reading comprehension ability could be investigated in terms of gender, in other words, the research could be carried out with sufficient numbers of participants from each sex.

Acknowledgment - We wish to express my sincere thanks and gratitude to Mrs. Rezaii (the English teacher of my research) for providing the time for fulfilling this research project.

\section{References}

Abdi, R. (2013). The effect of using hypertext materials on reading comprehension ability of EFL learners.

Procedia - Social and Behavioral Sciences, 83, 557-562. http://dx.doi.org/10.1016/j.sbspro.2013.06.106

Attaran, M., Alias, N., \& Siraj, S. (2012). Learning culture in a smart school: A case study. Procedia - Social and Behavioral Sciences, 64, 417 - 423. http://dx.doi.org/10.1016/j.sbspro.2012.11.049

Attaran, M., \& Siraj, S. (2010). Smart school: Toward better performance. Working Paper at International Educational Technology Conference (IETC 2010). Istanbul University, Istanbul, Turkey. Retrieved April 27, 2014, from http://www.iet-c.net 
The effect of smart school programs on EFL reading comprehension in an academic context

Bahmani, R., Keshavarz, H., \& Ghajari, H. (2013). The effect of smart schools on the social skills of students. Interdisciplinary Journal of Contemporary Research in Business, 5(7), 151-159.

Day, R. R., \& Bamford, J. (1998). Extensive reading in the second language classroom. Cambridge University Press.

Esmaeili Fard, H., \& Nabifar, N. (2011). The effect of computer-assisted language learning (CALL) on reading comprehension in Iranian EFL context. Journal of Academic and Applied Studies, 1(4), 1-8.

Godwin-Jones, R. (1998). Language learning and the web. [Online document] Available: http://www.fln.vcu.edu/cgi/1.html

Huang, P. C., \& Pan, C. Y. (2009). The development and evaluation of a web-based college English outside reading system for EFL freshmen. The JALT CALL Journal, 5(3), 3-22.

Kulik, C . L., \& kulik, J.A. (1991). Effectiveness of computer-assisted instruction: An updated analysis. Computers in Human Behavior, 7, 75-94.

Lan, Y. J., Sung, Y. T., \& Chang K. E. (2006). Collaborative early EFL reading among distributed learners: A simulation pilot study. The JALT CALL Journal, 2(2), 53-65.

Liu, Y. (2007). A comparative study of learning styles between online and traditional students. Journal of Educational Computing Research, 37(1), 41-63.

Mahmudi, J., Nalchigar, S., \& Ebrahimi, S. B. (2008). Challenges of smart schools in Iran. Quarterly Journal of Educational Innovations, 7(27), 61-78.

Majidi, A. (2001). Superior systems: the future of education and the future of education, Tehran: SAMT Publication.

Marzban, A. (2011). Improvement of reading comprehension through computer-assisted language learning in Iranian intermediate EFL students. Procedia Computer Science, 3, 3-10.

Ong, E. T., \& Ruthven, K. (2010). The distinctiveness and effectiveness of science teaching in the Malaysian 'smart school'. Research in Science \& Technological Education, 28(1), 25-41.

Parsa, M. (1995). Learning psychology based on theories. Tehran: Sokhan Publications.

Preston, C., \& Mowbray, L. (2008). Use of SMART Boards for teaching, learning and assessment in kindergarten science. Teaching Science: The Journal of the Australian Science Teachers Association, 54(2), 50-53.

Puteh, M., \& Vicziany, A. M. (2004, July 5-9). How smart are Malaysia's smart schools? Paper presented at the 4th Global Congress on Engineering Education, Bangkok, Thailand.

Simsek, S. (2008). Students' attitudes towards integration of ICTs in a reading course: A case in Turkey. Computers \& Education, 51, 200-211.

Soltani, M. (2012). The structure of smart schools in the educational system. Journal of Basic and Applied Scientific Research, 2(6), 6250-6254.

Thang, S., Hall, C., Azman, H., \& Joyes, G. (2010). Supporting smart school teachers' continuing professional development in and through ICT: A model for change. International Journal of Education and Development using ICT, 6(2), 5-20.

Uneeco. (2003). ICT in education around the world: Tends, Problems and Prospects.

Wan Ali, W., Mohd Nor, H., Hamzah, A., \& Alwi, N. (2009). The conditions and level of ICT integration in Malaysian Smart Schools. International Journal of Education and Development using ICT, 5(2). Retrieved April 29, 2014, from http://ijedict.dec.uwi.edu/viewarticle.php?id=618

Wood, G. (2004). Academic original sin: Plagiarism, the internet, and librarians. The Journal of Academic Librarianship, 30(3), 237-242.

Yang, Y. F., Wong, W. K., \& Yuh, H. C. (2008). A computer system of referential resolution to assess students' reading comprehension. Educational Technology \& Society, 11(4), 173-189.

Zain, M. Z. M., Murugaiah, P. (2004). Management Practice in Malaysian Smart schools: tasks and support analysis of the ICT implementation. IEEE international conference on advanced learning technologies, 30, 1008-1012. http://dx.doi.org/10.1109/ICALT.2004.1357739

Zufen, S. (2006). The use of new technologies in education. Tehran: SAMT Publication. 
Rostami, S., Akbari, O., \& Ghanizadeh, A. 